ISSN 0258-7122

Bangladesh J. Agril. Res. 38(1): 145-154, March 2013

\title{
YIELD AND QUALITY OF MANGO (Mangifera indica L.) AS INFLUENCED BY FOLIAR APPLICATION OF POTASSIUM NITRATE AND UREA ${ }^{* *}$
}

\author{
BABUL CHANDRA SARKER ${ }^{1}$ AND M. A. RAHIM ${ }^{2}$
}

\begin{abstract}
The experiment to determine the effects of $\mathrm{KNO}_{3}$ and urea in manipulating the harvesting time and increasing yield as well as quality of nine years old mango (Mangifera indica L.) cv. Amrapali plants was carried out at the BAU Germplasm Centre, Department of Horticulture, Bangladesh Agricultural University, Mymensingh during the period from September 2006 to July 2007. The five treatments included in the experiment were potassium nitrate at $4 \%$, $6 \%$ and $8 \%$; urea at $2 \%$ and $4 \%$ and the control (water spray). Foliar spraying of urea at $4 \%$ exhibited better performance in relation to terminal shoot length, number of leaves and leaf area and potassium nitrate at $4 \%$ gave superior results with respect to length and breadth of panicle and number of secondary branches per panicle compared to control. The plants sprayed with $\mathrm{KNO}_{3}$ at $4 \%$ expressed earlier panicle appearance by 17 days as compared to delayed appearance of panicle in untreated control plants. The plants received $\mathrm{KNO}_{3}$ at $4 \%$ produced the highest number of panicles per plant (220.67) whereas the control plants had the least number of panicles (107.67). Regardless of concentration, $\mathrm{KNO}_{3}$ and urea manifested slightly earlier harvest (5 days) compared to control. Plants treated with $\mathrm{KNO}_{3}$ at $4 \%$ noted the highest number of fruits per plant (136.67) compared to control (62.67). The treatment urea at $4 \%$ resulted in the biggest fruit (202.83g) and the control plants exhibited the smallest fruit (175.00g). Potassium nitrate at $4 \%$ gave maximum yield ( $23.14 \mathrm{~kg} / \mathrm{plant})$ as compared to minimum yield (9.12 kg/plant) in the control (water spray).
\end{abstract}

Keywords: Yield and quality of mango, foliar application, potassium nitrate, urea.

\section{Introduction}

So far as delicacy is concerned, mango (Mangifera indica L.) is considered to be the number one fruit of Bangladesh which is nutritionally superior and one of the most valuable fruits of the world. In Bangladesh, it occupies 51.012 thousand hectares of land and total production of mango is 242.605 thousand tons with an average yield of 4.75 tons per hectare (BBS, 2005), which is considerably a low yield mitigating the national demand. Irregular or erratic flowering, low fruit set as well as fruit retention leading to low yield and fruits of poor quality and short availability period are also the main problems in mango production. Spraying of

\footnotetext{
** A part of Ph. D. research.

${ }^{1}$ Principal Scientific Officer, Pomology Division, Horticulture Research Centre, Bangladesh Agricultural Research Institute (BARI), Joydebpur, Gazipur, ${ }^{2}$ Professor, Department of Horticulture, Bangladesh Agricultural University (BAU), Mymensingh, Bangladesh.
} 
$\mathrm{KNO}_{3}(6 \%)$ during September-October significantly increased the percentage of flowering shoots and the number of mixed panicle and vegetative shoots/auxilary branches (Rojas et al., 1993). Foliar spraying of urea and $\mathrm{KNO}_{3}$ significantly increased the flowering percentage of mango (Rajput and Singh, 1988; Catchpoole and Bally, 1993). Generally, $\mathrm{KNO}_{3}$ gives better results in flowering and fruiting (Khattab et al., 2006). Application of $\mathrm{KNO}_{3}$ advanced flowering and harvesting date, increased yields and reduced alternate bearing (Sergent et al., 1997). Sharma et al. (1990) obtained maximum number of fruits per plant and fruit weight of mango cv. Langra at Madhya Pradesh, India from the urea treatment. Gupta and Brahmachari (2004) found maximum yield using urea. Potassium nitrate concentrations especially in combination with urea gave better results for most of the flowering and yield parameters of 'Tommy Atkins' mango in Ethiopia (Yeshitela et al., 2005). The research regarding regulation of flowering and harvesting time, increasing yield and quality of mango using $\mathrm{KNO}_{3}$ and urea is inadequate in Bangladesh. With these views, the present study was aimed at investigating the effects of $\mathrm{KNO}_{3}$ and urea on harvesting time, yield as well as quality attributes of mango.

\section{Materials and Method}

The experiment was carried out at the BAU Germplasm Centre, Department of Horticulture, Bangladesh Agricultural University, Mymensingh which is located at $24^{0} 26^{\prime}$ latitude and $90^{\circ} 15^{\prime}$ longitude with an altitude of $8.3 \mathrm{~m}$ above the sea level during September 2006 to July 2007. Investigations related to bio-chemical analysis were carried out in the Department of Biochemistry of Bangladesh Agricultural University (BAU), Mymensingh. The cultivar Amrapali was used in the study. The age of the plants was 9 years at the initiation of experiment with a plant spacing of $5 \mathrm{~m} \times 5 \mathrm{~m}$. The experiment was laid out in a Randomized Complete Block Design (RCBD) with 3 replications. Six treatments viz. Potassium nitrate $\left(\mathrm{KNO}_{3}\right)$ at $4 \%, 6 \%$ and $8 \%$; Urea at $2 \%$ and $4 \%$ and Control (water spray) were used in the study. The solutions of $4,6 \%$ and $8 \% \mathrm{KNO}_{3}$ were prepared by dissolving 40, 60 and $80 \mathrm{~g}$ of $\mathrm{KNO}_{3}$ into 1 litre of fresh water each with 3 drops of Tween 80 . The urea solutions of 2 and $4 \%$ were prepared by dissolving 20 and $40 \mathrm{~g}$ of urea in 1 litre of fresh water each with 3 drops of Tween 80, respectively. The $\mathrm{KNO}_{3}$ and urea solutions as per treatment were sprayed to the plants on 15 November 2006. The data of the following parameters were recorded: length of terminal shoot, number of leaves per terminal shoot, leaf area, length and breadth of panicle, number of secondary branches per panicle, date of first panicle appearance, number of panicles per plant at 10 day intervals, fruit set per panicle, number of fruits retained per panicle at 10 day intervals starting from pea stage upto harvest, date of harvest, number of fruits per plant, average fruit weight, fruit length, fruit breadth, fruit thickness, edible portion, stone pulp ratio, peel pulp ratio, yield, shelf life, TSS, 
$\mathrm{pH}$, titratable acidity, vitamin $\mathrm{C}$, dry matter content, reducing sugar, non reducing sugar and total sugar content. The length, breadth and number leaves of ten randomly selected terminal shoots at flowering stage were measured and the average was worked out. Leaf area was measured for all the 50 leaves taking 5 from each of ten above selected shoots by a leaf area meter and expressed as square centimeter. The length and breadth of panicle and number of secondary branches per panicle of 10 randomly tagged panicles covering the whole tree was recorded and the average was worked out. Ten panicles were randomly selected from each treatment. The initial number of fruits of each panicle and the fruits to be retained per panicle was recorded at 10 day intervals starting from pea stage up to harvest were counted and the average was worked out. Ten randomly selected fruits from each plant were used for taking fruit characters and the average was measured. After harvest, ten randomly selected fruits were allowed to ripen at room temperature and fruit quality was determined using 10 fruits per tree. Total soluble solid (TSS) of 10 fully ripe fruits for each treatment was estimated by a hand refractometer and the average was worked out. The titratable acidity (Ranganna, 1979), vitamin C content (Plummer, 1971), reducing sugar content (Miller, 1972) and total sugar content (Jayaraman, 1981) of mango pulp were determined. The recorded data on different parameters of the experiment were tabulated and analyzed and the treatment means were separated by Least Significant Difference (LSD) test at $5 \%$ level of significance.

\section{Results and Discussion}

\section{Effects of $\mathrm{KNO}_{3}$ and urea on leaf, shoot and panicle characters of mango}

The treatments exhibited statistically more pronounced effects in terms of length of terminal shoot, number of leaves per terminal shoot, leaf area, panicle length, panicle breadth and number of secondary branches per panicle (Table 1). Both urea and $\mathrm{KNO}_{3}$ caused an increase in the terminal shoot length when compared to control. The plants treated with urea at $4 \%$ demonstrated the longest terminal shoot with $12.73 \mathrm{~cm}$ which, was followed by $\mathrm{KNO}_{3}$ at $4 \%(12.50 \mathrm{~cm})$, urea at $2 \%$ $(12.30 \mathrm{~cm})$ and $\mathrm{KNO}_{3}$ at $6 \%(11.07 \mathrm{~cm})$ as against the shortest shoot in control plants $(8.24 \mathrm{~cm})$. Maximum number of leaves (13.37) was registered in the plants sprayed with urea at $4 \%$, which was statistically identical to those of $\mathrm{KNO}_{3}$ at $4 \%$ (12.89) and urea at $2 \%(11.37)$, whereas the lowest leaves were recorded in the plants treated with $\mathrm{KNO}_{3}$ at $8 \%$ (7.10). Foliar spraying of urea at $4 \%$ resulted in the highest leaf area $\left(60.08 \mathrm{~cm}^{2}\right)$ as compared to the least leaf area with 38.53 $\mathrm{cm}^{2}$ in control. Rajput and Singh (1988) also experienced a significant increase in vegetative growth in mango cv. Dashehari caused by urea. Spraying of both $\mathrm{KNO}_{3}$ and urea solutions irrespective of concentration exhibited longer panicles as compared to the shorter panicles in the control. Foliar spraying of mango plants with $\mathrm{KNO}_{3}$ at $4 \%$ noted the longest panicle $(38.83 \mathrm{~cm})$, which was 
statistically identical to those of urea at $4 \%(36.43 \mathrm{~cm})$ and $\mathrm{KNO}_{3}$ at $6 \%(34.90$ $\mathrm{cm})$, compared to the shortest panicles $(25.19 \mathrm{~cm})$ in control plants. This result corroborates the findings of Sanyal et al., (1996) who reported that $\mathrm{KNO}_{3}$ caused an increase in length of panicle in cultivars Himsagar and Langra. Dalal et al. (2005) also reported the highest panicle length. The widest panicle $(31.87 \mathrm{~cm})$ was obtained from the plants sprayed with KNO3 at $4 \%$. The control plants manifested the narrowest panicle $(19.83 \mathrm{~cm})$. Regardless of concentration, $\mathrm{KNO}_{3}$ and urea expressed better performance with respect to number of secondary branches per panicle compared to control (water spray).

Table 1. Effects of $\mathrm{KNO}_{3}$ and urea on leaf, shoot and panicle characters of mango.

\begin{tabular}{c|c|c|c|c|c|c}
\hline Treatments & $\begin{array}{c}\text { Length of } \\
\text { terminal } \\
\text { shoot }(\mathrm{cm})\end{array}$ & $\begin{array}{c}\text { No. of } \\
\text { leaves/ } \\
\text { terminal } \\
\text { shoot }\end{array}$ & $\begin{array}{c}\text { Leaf area } \\
\left(\mathrm{cm}^{2}\right)\end{array}$ & $\begin{array}{c}\text { Length } \\
\text { of } \\
\text { panicle } \\
(\mathrm{cm})\end{array}$ & $\begin{array}{c}\text { Breadth of } \\
\text { panicle } \\
(\mathrm{cm})\end{array}$ & $\begin{array}{c}\text { No. of } \\
\text { secondary } \\
\text { branches/ } \\
\text { panicle }\end{array}$ \\
\hline $\mathrm{KNO}_{3}$ at $4 \%$ & 12.50 & 12.89 & 48.22 & 38.83 & 31.87 & 43.03 \\
$\mathrm{KNO}_{3}$ at $6 \%$ & 11.07 & 8.37 & 44.83 & 34.90 & 24.33 & 39.20 \\
$\mathrm{KNO}_{3}$ at $8 \%$ & 9.00 & 7.10 & 43.62 & 34.00 & 22.20 & 38.40 \\
$\mathrm{Urea}$ at $2 \%$ & 12.30 & 11.37 & 44.81 & 32.67 & 22.00 & 38.07 \\
Urea at $4 \%$ & 12.73 & 13.37 & 60.08 & 36.43 & 28.07 & 41.73 \\
Control & 8.24 & 10.95 & 38.53 & 25.19 & 19.83 & 28.50 \\
\hline $\mathrm{CV}(\%)$ & 8.21 & 8.15 & 6.69 & 5.24 & 7.44 & 4.99 \\
$\mathrm{LSD}(0.05)$ & 1.58 & 1.64 & 5.68 & 3.20 & 3.35 & 3.46 \\
\hline
\end{tabular}

Effect of $\mathrm{KNO}_{3}$ and urea on panicle appearance and number of panicles per plant

The first appearance of panicle ranged from 16 December 2006 to 2 January 2007 (Table 2). The treatment $\mathrm{KNO}_{3}$ at $4 \%$ manifested earlier panicle appearance by 17 days as compared to the delayed appearance in control plants. The earlier appearance in $\mathrm{KNO}_{3}$ treated plants might be due to the fact that $\mathrm{KNO}_{3}$ acts as a bud dormancy breaking agent (Tongumpai et al., 1989). Earlier flowering in mango promoted by foliar spray of $\mathrm{KNO}_{3}$, which promotes ethylene biosynthesis has also been reported by Mosqueda-Vazquez and Avila-Resendiz (1985). Dalal et al., (2005) claimed flowering earliness (27-30 days earlier) in mango cv. Pairy sprayed with potassium nitrate in Akola, Maharashtra, India. Sergent and Leal (1989) reported that flower emerged 21 days earlier than control when $\mathrm{KNO}_{3}$ applied on 19 November which gives support to the present result. Marked significant differences at all dates of data record were registered in terms of number of panicles per plant due to different treatments (Table 1). The treatment $\mathrm{KNO}_{3}$ at $4 \%$ produced the highest number of panicles (28) on 24 December 2006, when $\mathrm{KNO}_{3}$ at $8 \%$ and the control did not produce any inflorescence. The plants received KNO3 at $4 \%$ always produced the highest number of panicles per plant 
Table 2. Effects of $\mathrm{KNO}_{3}$ and urea on appearance and number of panicles per plant of mango.

\begin{tabular}{|c|c|c|c|c|c|c|c|c|}
\hline \multirow{2}{*}{ Treatments } & \multirow{2}{*}{$\begin{array}{l}\text { Date of first } \\
\text { appearance of } \\
\text { panicle }\end{array}$} & \multicolumn{7}{|c|}{ Number of panicles emerged per plant at } \\
\hline & & 24.12 .06 & 03.01 .07 & 13.01 .07 & 23.01 .07 & 02.02 .07 & 12.02 .07 & 22.02 .07 \\
\hline $\mathrm{KNO}_{3}$ at $4 \%$ & 16.12 .06 & 28.00 & 83.00 & 189.33 & 210.67 & 220.00 & 220.67 & 220.67 \\
\hline $\mathrm{KNO}_{3}$ at $6 \%$ & 23.12.06 & 2.00 & 6.00 & 9.67 & 28.33 & 146.33 & 162.33 & 162.33 \\
\hline $\mathrm{KNO}_{3}$ at $8 \%$ & 28.12.06 & 0.00 & 4.33 & 7.33 & 25.00 & 100.00 & 126.67 & 135.00 \\
\hline Urea at $2 \%$ & 21.12.06 & 10.00 & 14.67 & 56.67 & 116.00 & 162.00 & 163.67 & 165.33 \\
\hline Urea at $4 \%$ & 19.12.06 & 12.00 & 16.33 & 74.33 & 137.67 & 194.33 & 196.00 & 196.00 \\
\hline Control & 02.01 .07 & 0.00 & 2.33 & 6.33 & 20.33 & 85.67 & 101.33 & 107.67 \\
\hline CV (\%) & - & - & 10.79 & 9.33 & 7.11 & 7.62 & 5.26 & 4.88 \\
\hline LSD (0.05) & & - & 4.14 & 9.73 & 11.60 & 20.98 & 15.48 & 14.60 \\
\hline
\end{tabular}

Table 3. Effects of $\mathrm{KNO}_{3}$ and urea on fruit set and fruit retention per panicle.

\begin{tabular}{|c|c|c|c|c|c|c|c|c|c|c|c|}
\hline \multirow[b]{2}{*}{ Treatments } & \multirow{2}{*}{$\begin{array}{c}\text { Fruit set } \\
\text { per } \\
\text { panicle }\end{array}$} & \multicolumn{10}{|c|}{ Number of fruits retained per panicle at } \\
\hline & & $\begin{array}{c}25.03 . \\
07\end{array}$ & $\begin{array}{c}04.04 . \\
07\end{array}$ & $\begin{array}{c}14.04 . \\
07\end{array}$ & $\begin{array}{c}24.04 . \\
07\end{array}$ & $\begin{array}{c}04.05 . \\
07\end{array}$ & $\begin{array}{c}14.05 . \\
07\end{array}$ & $\begin{array}{c}24.05 . \\
07\end{array}$ & $\begin{array}{c}03.06 . \\
07\end{array}$ & $\begin{array}{c}13.06 . \\
07\end{array}$ & Harvest \\
\hline $\mathrm{KNO}_{3}$ at $4 \%$ & 17.27 & 12.00 & 4.60 & 2.27 & 2.13 & 2.07 & 1.87 & 1.73 & 1.70 & 1.63 & 1.63 \\
\hline $\mathrm{KNO}_{3}$ at $6 \%$ & 19.87 & 19.87 & 7.07 & 1.40 & 1.20 & 1.07 & 1.07 & 1.03 & 1.00 & 1.00 & 1.00 \\
\hline $\mathrm{KNO}_{3}$ at $8 \%$ & 8.50 & 8.50 & 2.60 & 1.10 & 0.93 & 0.83 & 0.83 & 0.83 & 0.83 & 0.83 & 0.80 \\
\hline Urea at $2 \%$ & 12.50 & 9.43 & 4.00 & 1.30 & 1.27 & 1.23 & 1.20 & 1.17 & 1.10 & 1.10 & 1.03 \\
\hline Urea at 4\% & 16.09 & 12.80 & 5.28 & 1.90 & 1.63 & 1.53 & 1.53 & 1.53 & 1.47 & 1.40 & 1.37 \\
\hline Control & 6.50 & 6.50 & 2.33 & 1.03 & 0.83 & 0.80 & 0.77 & 0.77 & 0.77 & 0.73 & 0.73 \\
\hline CV (\%) & 11.32 & 8.52 & 11.01 & 10.11 & 11.21 & 10.85 & 9.37 & 7.54 & 7.43 & 7.84 & 7.40 \\
\hline LSD (0.05) & 2.77 & 1.78 & 0.86 & 0.27 & 0.27 & 0.25 & 0.25 & 0.16 & 0.15 & 0.16 & 0.15 \\
\hline
\end{tabular}


Table 4. Effects of $\mathrm{KNO}_{3}$ and urea on number of fruits per plant and fruit characters of mango.

\begin{tabular}{|c|c|c|c|c|c|c|c|c|c|c|}
\hline \multirow[t]{2}{*}{ Treatments } & \multirow{2}{*}{$\begin{array}{l}\text { Date of } \\
\text { harvest }\end{array}$} & \multirow{2}{*}{$\begin{array}{l}\text { Number of } \\
\text { fruits per } \\
\text { plant }\end{array}$} & \multicolumn{4}{|c|}{ Fruit } & \multirow{2}{*}{$\begin{array}{c}\text { Edible } \\
\text { portion } \\
(\%) \\
\end{array}$} & \multirow{2}{*}{$\begin{array}{l}\text { Stone } \\
\text { pulp } \\
\text { ratio }\end{array}$} & \multirow{2}{*}{$\begin{array}{l}\text { Peel } \\
\text { pulp } \\
\text { ratio }\end{array}$} & \multirow{2}{*}{$\begin{array}{l}\text { Shelf } \\
\text { Life }\end{array}$} \\
\hline & & & $\begin{array}{l}\text { Weight } \\
\text { (g) }\end{array}$ & $\begin{array}{l}\text { Length } \\
(\mathrm{cm})\end{array}$ & $\begin{array}{c}\text { Breadth } \\
\text { (cm) }\end{array}$ & $\begin{array}{c}\text { Thick- } \\
\text { ness }(\mathrm{cm})\end{array}$ & & & & \\
\hline $\mathrm{KNO}_{3}$ at $4 \%$ & 20.06 .07 & 136.67 & 193.07 & 9.15 & 6.45 & 5.82 & 67.53 & 0.27 & 0.22 & 10.00 \\
\hline $\mathrm{KNO}_{3}$ at $6 \%$ & 20.06.07 & 105.00 & 184.47 & 9.09 & 6.34 & 5.72 & 66.83 & 0.27 & 0.22 & 9.30 \\
\hline $\mathrm{KNO}_{3}$ at $8 \%$ & 20.06 .07 & 96.67 & 180.60 & 8.91 & 6.41 & 5.69 & 64.99 & 0.29 & 0.25 & 8.08 \\
\hline Urea at $2 \%$ & 20.06.07 & 94.66 & 184.06 & 9.07 & 6.22 & 5.66 & 65.64 & 0.28 & 0.24 & 8.27 \\
\hline Urea at $4 \%$ & 20.06.07 & 108.33 & 202.83 & 9.22 & 6.46 & 6.02 & 68.15 & 0.25 & 0.22 & 10.33 \\
\hline Control & 25.06 .07 & 62.67 & 175.00 & 8.75 & 6.32 & 5.54 & 64.78 & 0.29 & 0.25 & 7.67 \\
\hline CV (\%) & - & 7.08 & 4.43 & 6.64 & 5.64 & 4.47 & 3.16 & 4.50 & 5.53 & 5.29 \\
\hline LSD (0.05) & - & 12.95 & 15.03 & NS & NS & NS & NS & 0.03 & 0.03 & 0.86 \\
\hline
\end{tabular}

NS: Not significant

Table 40. Effects of $\mathrm{KNO}_{3}$ and urea on quality attributes of mango.

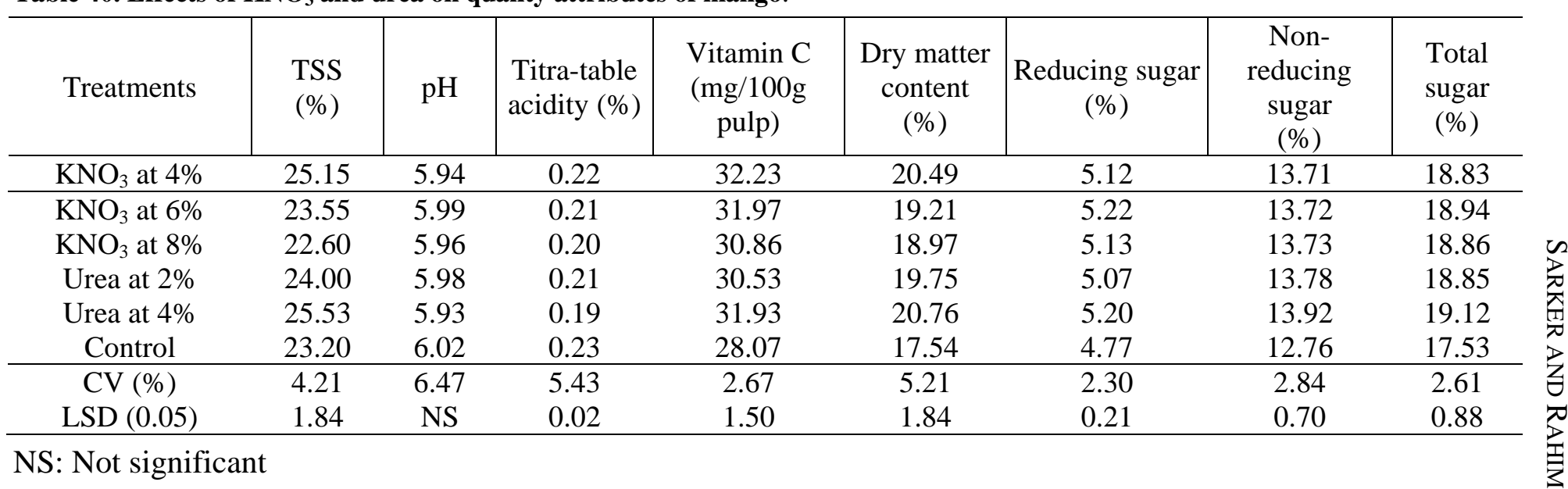


and it was recorded with 220.67 per plant on 22 February 2007. On the contrary, the control plants produced the least number of panicles (107.67) on the same date. Foliar spraying of $\mathrm{KNO}_{3}$ significantly increased the flowering percentage (Rajput and Singh, 1988; Catchpoole and Bally, 1993). Dalal et al. (2005) obtained the greatest number of panicles per mango tree cv. Pairy in Akola, India when sprayed with potassium nitrate.

\section{Effect of $\mathrm{KNO}_{3}$ and urea on fruit set and fruit retention per panicle}

The treatments exerted profound significant influences on fruit set per panicle (Table 3). Maximum fruit set per panicle was recorded in the treatment $\mathrm{KNO}_{3}$ at $6 \%$ (19.87) followed by $\mathrm{KNO}_{3}$ at $4 \%$ (17.27) and urea at 4\% (16.09), whereas minimum fruit set was noticed from the control (6.50) plants. The number of fruits per panicle always differed significantly among the chemical treatments (Table 3). The plants sprayed with $\mathrm{KNO}_{3}$ at $6 \%$ manifested higher number of fruits per panicle starting from 25 March (19.87) upto 4 April (7.07) as compared to lower panicles both on 25 March (6.50) and 4 April (2.33) in control. From 14 April 2007 up to harvest, the treatment $\mathrm{KNO}_{3}$ at $4 \%$ always had the highest number of fruits per panicle and at harvest, it was with a value of 1.63 , which was followed by urea at $4 \%$ (1.37) as against the least fruits per panicle from the control plants (0.73). The higher fruit set and retention in $\mathrm{KNO}_{3}$ at $4 \%$ has got similarity with the findings of Oosthuyse (1997) who observed the greatest increase in fruit retention of mango cv. Tommy Atkins due to single spraying of $\mathrm{KNO}_{3}$ at $4 \%$. Dalal et al., (2005) also reported the highest fruit set (2.08\%) with potassium nitrate in mango cv. Pairy in Akola, Maharashtra, India. Khattab et al. (2006) claimed that $\mathrm{KNO}_{3}$ at $4 \%$ had improved flowering and fruiting in mango cultivars Ewais and Sidik, in Giza, Egypt.

\section{Effect of $\mathrm{KNO}_{3}$ and urea on date of harvest, number of fruits per plant, fruit characters and yield}

The harvest time varied from 20.06.07 to 25.06.07 where urea and $\mathrm{KNO}_{3}$ irrespective of concentration demonstrated slightly earlier harvest as compared to delayed harvest in control plants (Table 4). Mosqueda-Vazquez and AvilaResendiz (1985) and Sergent et al. (1997) opined that foliar spraying of $\mathrm{KNO}_{3}$ advanced harvesting date. The number of fruits per plant, fruit weight, stone pulp ratio, peel pulp ratio, yield and shelf life, were significantly influenced by the treatments (Table 4) although no significant variations were noted in fruit length, fruit breadth, fruit thickness and edible portion. The plants treated with $\mathrm{KNO}_{3}$ at $4 \%$ produced the highest number of fruits per plant (136.67). The second highest number of fruits (108.33) per plant was appeared in the treatment urea at $4 \%$ followed by $\mathrm{KNO}_{3}$ at $6 \%$ (105.00) compared to control (62.67) the least. Plants treated with urea at $4 \%$ recorded maximum fruit weight (202.83g) which was statistically at par to that of $\mathrm{KNO}_{3}$ at $4 \%(193.07 \mathrm{~g})$. The control plants exhibited minimum fruit weight $(175.00 \mathrm{~g})$. These results are very close to the findings of 
Sharma et al. (1990) who reported maximum fruit weight (174.9 g) with 4\% urea treatment followed by the $3 \% \mathrm{KNO}_{3}$ treatment. Gupta and Brahmachari (2004) also obtained the highest fruit size, fruit weight and yield with spraying of urea at $4 \%$ at Bihar, India corroborate the findings of current study. The least stone pulp ratio was obtained from the plants treated with urea at $4 \%(0.25)$ followed by $\mathrm{KNO}_{3}$ at $4 \%(0.27)$ and $\mathrm{KNO}_{3}$ at $6 \%(0.27)$ as compared to the highest ratio $(0.29)$ in control. The variation in peel pulp ratio was found narrow from 0.22 to 0.25 . The treatments urea at $4 \%, \mathrm{KNO}$ at $4 \%$ and $\mathrm{KNO}_{3}$ at $6 \%$ demonstrated the same but least peel pulp ratio (0.22) as against the highest ratio in control (0.25). Regardless of concentration, all the treatments favourably increased the yield compared to control. The treatment $\mathrm{KNO}_{3}$ at $4 \%$ recorded the maximum yield of $23.14 \mathrm{~kg} /$ plant. The plants sprayed with urea at $4 \%$ showed the second highest yield (19.97 kg/plant) followed by $\mathrm{KNO}_{3}$ at $6 \%$ (18.55 kg/plant) as compared to the lowest yield $9.12 \mathrm{~kg} / \mathrm{plant}$ in control. The results of the present investigation are in agreement with the findings of Oosthuyse (1997) who indicated that $\mathrm{KNO}_{3}$ sprayed at 2 or $4 \%$ increased yield correspondent with the greatest increase in fruit retention. The highest fruit yield due to spraying of potassium nitrate in mango cv. Pairy in Akola, Maharashtra, India (Dalal et al., 2005) has got the similarity with the present result. Jain (2006) indicated that single and double spray treatment with $4 \%$ urea gave maximum yield in Madhya Pradesh, India. The plants treated with $4 \%$ urea solution exhibited the highest shelf life (10.33 days) which was closely followed by $\mathrm{KNO} 3$ at $4 \%$ (10.00 days), and $\mathrm{KNO}_{3}$ at $6 \%$ (9.30 days), while the lowest shelf life (7.67 days) was noticed in the control plants. Irrespective of concentration, both urea and potassium nitrate manifested a marked increase in shelf life when compared with the plants under control.

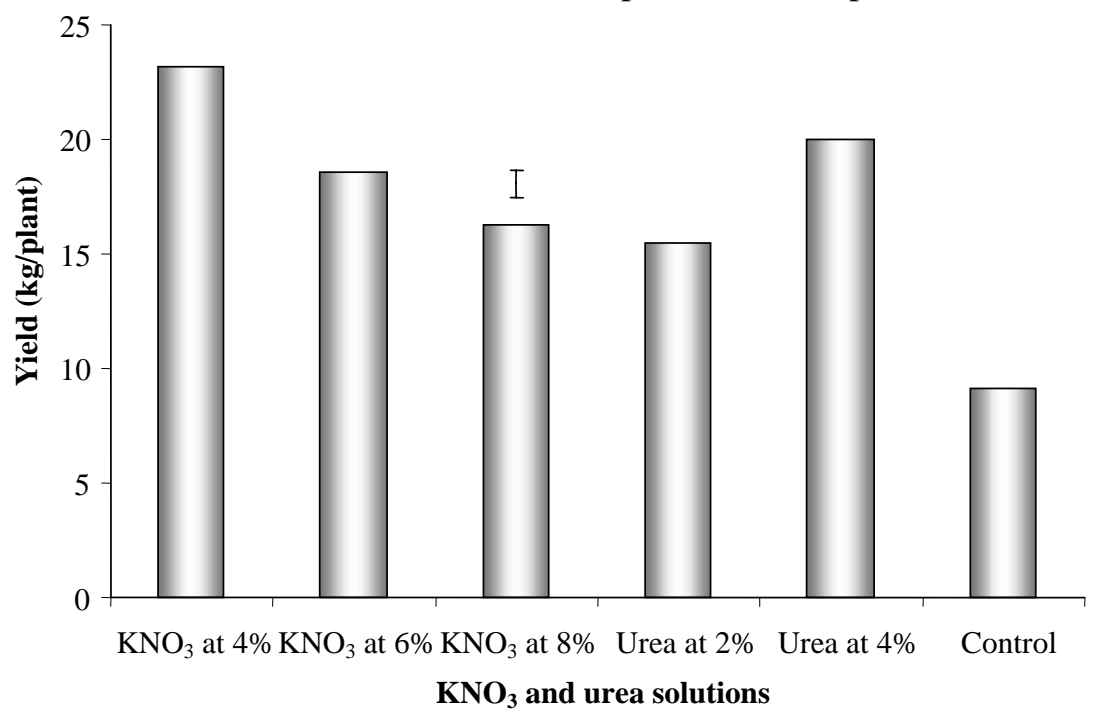

Fig. 1. Effect of KNO3 and urea on the yield per plant of mango. (Vertical bar represents LSD at $5 \%$ level). 


\section{Effects of $\mathrm{KNO}_{3}$ and urea on qualitative characters of mango}

The treatments exhibited significant variations with respect to TSS, titratable acidity, vitamin $\mathrm{C}$, dry matter content, reducing sugar, non reducing sugar and total sugar content except $\mathrm{pH}$, where no significant variation among the treatments was observed (Table 5). Urea solution at $4 \%$ recorded the maximum TSS content (25.53\%) which was followed by $\mathrm{KNO}_{3}$ at $4 \%(25.15 \%)$ and urea at $2 \%(24.00 \%)$ as against the least TSS content in plants treated with $\mathrm{KNO}_{3}$ at $8 \%$ (22.60\%). The minimum value of titratable acidity was observed in the treatment urea at $4 \%(0.19 \%)$ and the maximum $(0.23 \%)$ in control plants. In general, both KNO3 and urea registered statistically similar but higher vitamin $\mathrm{C}$ content compared to control. The treatment $\mathrm{KNO}_{3}$ at $4 \%$ exhibited maximum vitamin $\mathrm{C}$ content (32.23 mg/100g pulp). On the contrary, the control plants recorded the least vitamin C content ( $28.07 \mathrm{mg} / 100 \mathrm{~g}$ pulp). Plants spraying with urea at $4 \%$ exhibited the highest dry matter content $(20.76 \%)$ as against the lowest dry matter content in the control (17.54\%). Both urea and potassium nitrate irrespective of concentration recorded statistically similar and higher reducing and non reducing sugar content as compared to control. In general, both $\mathrm{KNO}_{3}$ and urea registered higher total sugar content as compared to the lowest content in control. The treatment urea at $4 \%$ produced maximum total sugar content (19.12\%), whereas the control treatment manifested the lowest (17.53\%) sugar content. The results of the investigation lend support to the findings of Rajput and Singh (1988) who found significant increase in fruit quality due to foliar spraying of urea. Ghosh and Chattopadhyay (1999) indicated that plants treated with 5\% urea, however increased fruit size and weight, TSS, the contents of ascorbic acid, reducing and total sugars in the fruits and also decreased fruit acidity which is identical to the present results.

\section{Conclusion}

Foliar application of $4 \% \mathrm{KNO}_{3}$ or $4 \%$ urea had little effect on the manipulation of harvesting time but both of these two chemicals at the same concentrations improved the yield as well as quality attributes of mango fruit.

\section{References}

BBS. 2005. Yearbook of Agricultural Statistics of Bangladesh 2004. Bangladesh Bureau of Statistics, Ministry of Planning. Govt. of the People's Republic of Bangladesh. P. 90.

Catchpoole, D. W. and I. S. E. Bally. 1993. Earlier flowering and more fruit. Mango Care Newsl. $8: 2-3$.

Dalal, S. R, V. S. Gonge, B. J. Jadhao and N. D. Jogdande, 2005. Effect of chemical on flowering and fruit yield of mango cv. Pairy. International J. Agric. Sci. 1 (1): 24-25.

Ghosh, S. N. and N. Chattopadhyay. 1999. Foliar application of urea on yield and physico-chemical composition of mango fruits cv. Himsagar under rainfed condition. Hort. J. 12 (1): 21-24. 
Gupta, R. K. and V. S. Brahmachari. 2004. Effect of foliar application of urea, potassium nitrate and NAA on fruit retention, yield and quality of mango cv. Bombai. Orissa $J$. Hort. 32 (2): 7-9.

Jain, P. K. 2006. Fruit drop, yield and quality of mango as influenced by biozyme and urea sprays. Indian J. Hort. 63 (4): 453-454.

Jayaraman, J. 1981. Laboratoy Mannual in Biochemistry. Wiley Eastern Ltd., New Delhi, India.

Khattab, M. M, G. M. Haseeb, A. E. Shaban and M. A. Arafa. 2006. Effect of paclobutrazol and potassium nitrate on flowering and fruiting of Ewais and Sidik mango trees. Bulletin of Faculty of Agriculture, Cairo University. 57 (1): 107-123.

Miller, G. L. 1972. Use of Dinitro Salicylic Acid Reagent for determination of reducing sugar. Anal. Chem. 31: 426-428.

Mosqueda-Vazquez, R and C. Avila-Resendiz, 1985. Floral induction of Mango with $\mathrm{KNO}_{3}$ applications and its inhibition by $\mathrm{AgNO}_{3}$ or $\mathrm{CoCl}_{2}$ application. Horticultura Mexicana. 1(1): 93-101.

Oosthuyse, S. A. 1997. Effect of $\mathrm{KNO}_{3}$ sprays to flowering mango trees on fruit retention, fruit size, tree yield and fruit quality. Acta Hort. 455: 359-366.

Plummer, D. T. 1971. An Introduction to Practical Biochemistry. Tata McGraw Hill Pub. Com: Ltd. Bombay, New Delhi. p. 229.

Rangana, S. 1979. Mannual of Analysis of fruit and vegetable products. Tata McGrawHill Pub. Co. Ltd., New Delhi. p. 634.

Rajput, C. B. S. and J. N. Singh. 1988. Effects of urea and $\mathrm{GA}_{3}$ sprays on the growth, flowering and fruiting characters of mango. Acta Hort. 231: 301-305.

Rojas, E., F. Leal and R. J. Campbell. 1993. Control of flowering and shooting in mango (Mangifera indica L.) with various chemical products. Proceedings of the International Society for Tropical and Tropical Horticulture. 37:142-147.

Sanyal, D., B. Biswas and S. K. Mitra. 1996. Studies on irregular bearing of mango (Mangifera indica L.). South Ind. Hort. J. 44 (12): 1-4.

Sergent, E. and F. Leal. 1989. Flowering induction in mango (Mangifera indica L.) with $\mathrm{KNO}_{3}$. Revista de la Facultad de Agronomia. 15(1-2): 17-32. [Cited from Hort. Abst. 68 (9): 962, 1998].

Sergent, E., D. Ferrari and F. Leal. 1997. Effects of potassium nitrate and Paclobutrazol on flowering induction and yield of mango (Mangifera indica L.) cv. Haden. Acta Hort. 455 : 180-187.

Sharma, T. R., P. K. R. Nair and M. K. Nema. 1990. Influence of foliar sprays of urea, $\mathrm{KNO}_{3}$ and NAA on physical composition of mango cv. Langra. Punjab Hort. J. 30 (1-4): 47-52.

Tongumpai, P., K. Hongsbhanich and C. H. Voon. 1989. Cultar for flowering regulation of mango in Thailand. Acta Hort. 219: 375-378.

Yeshitela, T., P. J. Robbertse and P. J. C. Stassen. 2005. Potassium nitrate and urea sprays affect flowering and yields of 'Tommy Atkins' (Mangifera indica) mango in Ethiopia. South African J. Plant and Soil. 22(1): 28-32. 